\title{
Spinální neurologie
}

\section{prof. MUDr. Ivana Štětkářová, CSc. - editorka hlavního tématu Neurologická klinika, 3. lékařská fakulta Univerzity Karlovy a FN KV, Praha}

V dnešním čísle jsme připravili pro čtenáře souborné články s problematikou spinální neurologie. Snažili jsme se podat ucelený pohled na tuto strukturu z různých směrů, proto jsme do tohoto čísla zařadili přehledové články. Ty se týkají neurologického vyšetření včetně diferenciální diagnostiky míšních poruch, zobrazovacích metod míchy (CT, MR) s představením i specifických metod, napríklad DWI (diffusion weighted images), sekvence DTI (diffusion tensor imaging) a funkční magnetické rezonance (fMRI). Dále zde předkládáme aktualizovaný pohled na elektrofyziologické metody a jejich pomoc $v$ diagnostice a monitoraci míšních dysfunkcí (EMG, somatosenzorické evokované potenciály, kožní perioda útlumu, sympatická kožní odpověd') a současné možnosti neurochirurgické léčby u akutních míšních lézí. Příkladem vzácné akutní mišní léze je spontánní epidurální hematom páteřního kanálu, který se mưže objevit jako možná komplikace antikoagulační terapie.

Jsou nemoci, které se týkají převážně míchy (amyotrofická laterální skleróza), jejichž př́ícina zatím není známa. Nebo je známa příčina míšní léze (poranění míchy, nádor, ischemie), ale není možné dostatečně a adekvátně léčit důsledky této poruchy vzhledem k ireverzibilitě postižení a malé regenerační schopnosti neuronů, jejich spojů a drah. Výzkum fyziologie a patofyziologie míchy se těmito otázkami zabývá v kontextu

\section{LITERATURA}

1. Bulsara KR, Iskandar BJ, Villavicencio AT, Pate Skene JH. A new millenium for spinal cord regeneration: growth-associated genes. Spine 2002; 27(17): 1946-1949.

2. Coumans JV1, Lin TT, Dai HN, MacArthur L, McAtee M, Nash C, Bregman BS. Axonal regeneration and functional recovery after complete spinal cord transection in rats by delayed treatment with transplants and neurotrophins. J Neurosci. 2001; 21(23): 9334-9344.

3. Gunduz A, Kumru H, Pascual-Leone A. Outcomes in spasticity after repetitive transcranial magnetic and transcranial di- s novými poznatky z oblasti genetiky, biochemie či farmakologie. Každý nový objev odstartuje množství experimentálních prací, které pak detailně zkoumají jednotlivé léčebné indikace.

Diagnostické metody včetně neurofyziologie určují míru míšního postižení na úrovni míšního segmentu, míšního reflexního oblouku, motoneuronu či jednotlivé míšní dráhy. V̌̌e směřuje k reparaci nervové tkáně již na buněčné či molekulární úrovni, např. v rámci transplantace nervové tkáně nebo při aplikaci neurotropních růstových faktorů do postižené tkáně. Po pretětí míchy u krys došlo po podání neurotropních faktorů spolu s transplantací nervové fetální tkáně k axonálnímu růstu v oblasti hrudní míchy s následným zlepšením lokomoce (Coumans et al., 2001). Úspěšná axonální regenerace axonů závisí nejen na jejich schopnosti regenerovat, ale roli hraje i prostředí, ve kterém bude zabezpečen jejich další růst. Důležitá je napríklad neuronální aktivace genů exprimujících růstové proteiny (např. GAP-43, growth associated protein), které jsou prítomné během axonální regenerace (Bulsara et al., 2002). Jako možný zdroj buněčné náhrady po poranění míchy se jeví transplantace prekurzorových oligodendrocytů (Li et Leung, 2015) a zkoumají se také kmenové buňky s využitím nanotechnologie (Nejati-Koshki et al., 2017). Elektrická stimulace míchy může pomoci vzprímenému stoji či bazální lokomoci (Mayr et al., 2016). Transkraniální magnetická stimulace aktivuje u osob s míšním poraněním vyšší procento kortikálních i spinálních motoneuronů než u zdravých jedinců; dochází k plastické reorganizaci nervového systému (Kumru et al., 2016). Plastické změny míšní zahrnují změny prahu dráždivosti motoneuronu, vodivou schopnost axonů a synaptické změny na motoneuronech. Předpokádá se, že k modulaci dochází během života a samožrejmě při jakémkoli inzultu. Celý koncept obnovy nervových funkcí vychází z indukce těchto plastických změn na míšní a kortikální úrovni. Při zvýšení senzitivního podnětu dochází k senzitizaci, dlouhotrvající potenciaci a k dalším jevům spojeným s chronickou míšní lézí. Senzitivní stimulace v periferní části nerového systému vyvolá krátkodobé změny ve specifických neuronálních míšních okruzích, zejména interneuronální síti v rámci reciproční inhibice la (Peret et al., 2003). Neuroplastické změny navozené napríklad repetitivní transkraniální magnetickou stimulací bývají bohužel zatím jen dočasné (Gunduz et al., 2014).

Spinální léze vedou ve většině prípadů k dlouhodobé disabilitě, proto je cílem různých reparačních metod (farmakologických, na genové úrovni, elektrostimulačních, apod.) funkční plastická reorganizace a pozitivní modulace míšních, supraspinálních a kortikálních neuronálních okruhů, které v konečném důsledku mohou vést k obnově porušených nervových funkcí. rect current stimulations. Neural Regen Res 2014; 9(7): 712-718. 4. Kumru H, Benito-Penalva J, Valls-Sole J, Murillo N, Tormos JM, Flores C, Vidal J. Placebo-controlled study of rTMS combined with Lokomat ${ }^{\oplus}$ gait training for treatment in subjects with motor incomplete spinal cord injury. Exp Brain Res 2016; 234(12): 3447-3455.

5. Li N, Leung GK. Oligodendrocyte precursor cells in spinal cord injury: a review and update. Biomed Res Int 2015; 2015: 235195

6. Mayr W, Krenn M, Dimitrijevic MR. Epidural and transcuta- neous spinal electrical stimulation for restoration of movement after incomplete and complete spinal cord injury. Curr Opin Neurol 2016; 29(6): 721-726.

7. Nejati-Koshki K, Mortazavi Y, Pilehvar-Soltanahmadi Y, Sheoran S, Zarghami N. An update on application of nanotechnology and stem cells in spinal cord injury regeneration. Biomed Pharmacother 2017; 90: 85-92.

8. Peret MA, Field-Fote EC, Floeter MK. Patterned sensory stimulation induces plasticity in reciprocal la inhibition in humans.J Neurosci 2003; 15(23): 2014-2018.

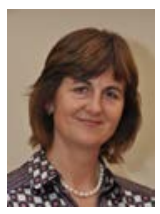

KORESPONDENČNII ADRESA AUTORA: 